Research Article

\title{
Application of Micronutrients Enhances the Quality of Kinnow Mandarin Infected by Citrus Greening Disease (Huanglongbing)
}

\author{
Zahoor Hussain ${ }^{1,2}$, Yasir Iftikhar ${ }^{3}$, Mustansar Mubeen ${ }^{3}$, Muhammad Zia Saleem $^{3}$, Muhammad Umer Na- \\ seer $^{3}$, Muhammad Luqman ${ }^{4}$, Raheel Anwar ${ }^{5}$, Faheem Khadija ${ }^{6}$ and Aqleem Abbas ${ }^{7}$
}

${ }^{1}$ Department of Horticulture, Ghazi University, D. G. Khan, Pakistan; ${ }^{2}$ Department of Horticulture, College of Agriculture, University of Sargodha, Sargodha; ${ }^{3}$ Department of Plant Pathology, College of Agriculture, University of Sargodha, Sargodha, Pakistan; ${ }^{4}$ Department of Agricultural extension, College of Agriculture, University of Sargodha, Sargodha; Institute of Horticultural Sciences, University of Agriculture, Faisalabad; ${ }^{6}$ Citrus Research Institute, Sargodha; ${ }^{7}$ State Key Laboratory of Agricultural Microbiology and Provincial Key Laboratory of Plant Sciences, P.R. China

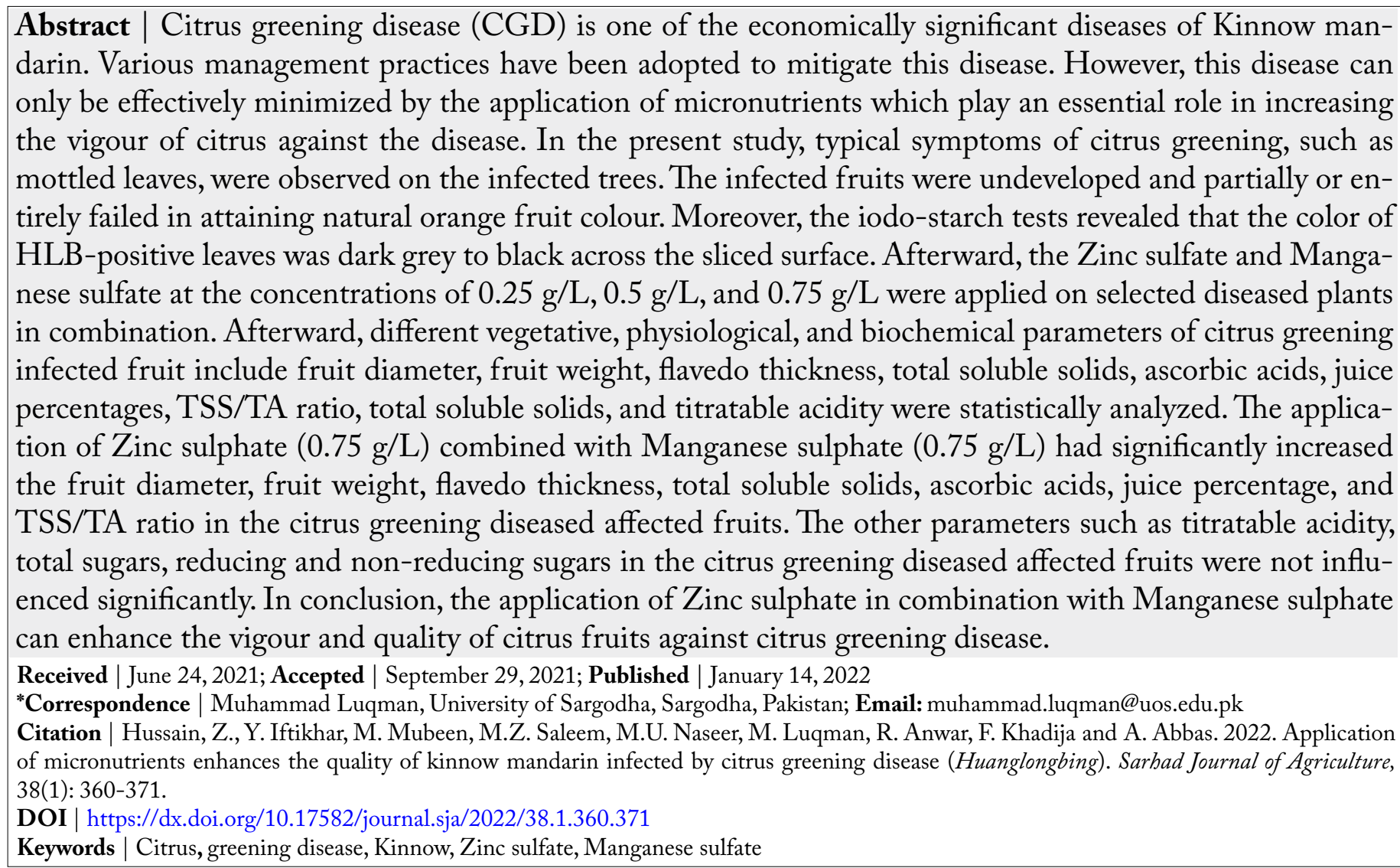

\section{Introduction}

$\mathrm{M}$ andarin (Citrus reticulata Blanco) is a widespread fruit crop gaining popularity due to its economic and nutritional value. In the fruit industry, citrus occupies a promising position globally, including Pakistan (Zhang et al., 2020; Shafiee et al., 2010). The citrus fruit is a very nutritious fruit having vitamin $\mathrm{C}$ in high amounts and vitamin $\mathrm{A}$ and $\mathrm{B}$ in a decent amount. Citrus fruit also contains calcium, iron, 
magnesium, copper, manganese, and phosphorus. Mandarin cv. Kinnow is one of the most popular and economic citrus fruit not only in Pakistan but worldwide. It has great economic value, and importance is established by its growth and production worldwide. Pakistan ranks at the $13^{\text {th }}$ position by display (Iftikhar et al., 2020).

Recently citrus production is hampered by citrus greening disease (CGD), also known as "Huanglongbing (HLB)" which has devastated citrus orchards in Pakistan (Iftikhar et al., 2016). CGD probably originated at the end of the $19^{\text {th }}$ century in China (Stelinski, 2019; Batool et al., 2007), named yellow shoot disease. CGD is devastating and widely distributed around the globe in citrus-growing areas. It is caused by gram-negative uncultivable phloem limited bacterium, but it has been cultivated successfully on biofilms (Ha et al., 2019). Candidatus Liberibacter has three strains (forms); Candidatus Liberibacter asiaticus (Las) in Asia, Candidatus Liberibacter africanus (Laf) in Africa; and the Candidatus Liberibacter americanus (Lam) originated from America and Barazil (Deng et al., 2019). Cochran reported citrus greening in Pakistan in 1976 and later was confirmed and characterized by Akhtar and Ahmad (1999). Chohan et al. (2007) provided the molecular evidence of citrus greening in citrus groves of Pakistan. The citrus greening disease symptoms include chlorosis of leaves, blotchy mottle, pale yellow, and excessive falling of leaves. In addition, the leaves of the infected plants become upright. In severe cases, twigs decline and ultimately lead to citrus tree decline at the later stages of infection (Bove, 2006).

The transmission of citrus greening disease is through insect vector psyllid and vegetative propagation Two different strains of citrus psyllid Trioza erytreae and Diaphorina citri, transmit the disease in Africa and Asia, respectively (Martini et al., 2020). Furthermore, the disease might be symptomless for many years in a plant host because of long latent period. This reason has made citrus greening disease extremely difficult to control. Though there are several integrated disease management (IDM) strategies, including utilization of pesticides for controlling psyllid vectors, for lessening of inoculum expulsion of HLB symptomatic trees, geographical isolation, and certification of nursery for the proliferation of bud wood sources that are pathogen-free the most effective strategy is to increase the vigour and quality of citrus fruits by nutrient management (Tran et al., 2020). Recently, foliar application of a few nourishing items, including micronutrients, has enhanced citrus fruits' vigor and quality against the citrus greening disease (Wang, 2019; Bassanezi et al., 2011). In Pakistan, most studies focus on the incidence and detection of citrus greening disease, and no reports are available regarding citrus greening disease management using nutrients (Giles, 2011). This study was aimed to manage the CGD through nutrition by enhancing the quality of citrus.

\section{Materials and Methods}

\section{Collection of samples and disease severity}

Samples were collected from the citrus greening infected trees of Kinnow based on symptomology and confirmed through the iodo-starch test. The trees were marked for nutritional application. Different Zinc sulphate concentrations $(0.25 \mathrm{~g} / \mathrm{L}, 0.5 \mathrm{~g} / \mathrm{L}, 0.75$ $\mathrm{g} / \mathrm{L})$ and Manganese sulfate $(0.25 \mathrm{~g} / \mathrm{L}, 0.5 \mathrm{~g} / \mathrm{L}, 0.75$ $\mathrm{g} / \mathrm{L})$ were applied on selected diseased plants in combination, and the same treatments were repeated after 15 days. Afterward, vegetative, physiological, and biochemical parameters were observed and analyzed statistically. At the harvesting stage, 20 fruits with three replications were randomly collected and subjected to physical and biochemical analysis. Symptomology followed by the iodo-starch test was the basic criterion for detecting disease (Saifullah et al., 2015). The fruits were collected based on a disease severity scale as mentioned previously (Akhtar and Ahmad, 1999).

\section{Scale Disease severity \\ 0 No symptoms on the fruits and leaves \\ 1 Blotchy mottled leaves (25\% leaves become infected) \\ 2 Lopsided fruits and color inversion (25-50\% sympto- matic canopy) \\ $3 \quad 51-75 \%$ Declined tree \\ $4>75 \%$ Declined tree}

Fruit diameter $(\mathrm{mm})$ and fruit weight $(\mathrm{g})$ : To determine the diameter and weight, of 20 fruits samples were selected/tree, and fruit diameter was calculated through radius with the help of vernier calliper and weighed using a digital electric balance, and average fruits weight calculated as gram (g)/fruit.

Number of healthy and aborted seeds per fruit: Calculate the number of healthy and aborted seeds per fruit. Peeled fruits were sorted to count the aborted seeds.

Flavedo and Albedo thickness (mm): The outer-colored layer of rind is called flavedo. Flavedo 
thickness was measured in $(\mathrm{mm})$ using a vernier calliper by separating the white layer of rind with a knife. The white inner layer of the rind is called albedo. It was measured by the difference of rind thickness minus flavedo thickness, and the result of albedo thickness was expressed in $(\mathrm{mm})$.

Juice percentage: About 20 harvested fruits were used to extract the juice. The extracts were then sieved to eliminate pulp and then weighed. Following formula was used to obtains the average juice (\%).

$$
\text { Juice }(\%)=\frac{\text { Juice weight per fruit }}{\text { Average fruit weight }} \times 100
$$

Total soluble solids (TSS): TSS were calculated through refractometer (ATAGO, RX 5000). Readings given by the refractometer were expressed as a percentage (\%) of TSS.

Ascorbic acid: The Ascorbic acid from juice were measured using the technique proposed by Ruck (1961). The following formula was used to measure the Ascorbic acid;

Ascorbic acid $(m g 100 g-1$ juice $)=\frac{I x R 1 \times V}{R \times W \times V I} \times 100$

$\mathrm{R} 1=$ dye $(\mathrm{ml})$ used to titrate against VI of aliquot (sample reading), $\mathrm{R}=\mathrm{ml}$ of dye used to titrate against $2.5 \mathrm{ml}(1 \mathrm{ml}$ standard ascorbic acid $+1.5 \mathrm{Ml}, 0.4 \%$ oxalic acid) of reference solution (Standard reading), VI= $\mathrm{ml}$ of juice taken for titration, $\mathrm{V}=$ Volume of the aliquot made by $0.4 \%$ oxalic acid and $\mathrm{W}=\mathrm{ml}$ of the juice takes.

Total sugars: The following formula was used for total sugars;

$$
\text { Total sugars }(\%)=25 \times(X / Z)
$$

Where;

$\mathrm{X}=$ Volume $(\mathrm{mL})$ of standard sugar solution titrated against $10 \mathrm{~mL}$ Fehling Solution and $Z=$ Volume $(\mathrm{mL})$ of sample aliquot used against $10 \mathrm{~mL}$ Fehling solution.

Sugars: Total sugars, non-reducing and reducing sugars were calculated followed the method elaborated by Hortwitz (1960).

Reducing sugars: The formula to calculate reducing sugars is as follows;

$$
\text { Reducing sugars (\%) }=6.25 \times(X / Y)
$$

$\mathrm{X}=$ Standard solution of sugar in $\mathrm{ml}$ used in titration against Fehling solution $(10 \mathrm{~mL})$ and $\mathrm{Y}=$ Sample volume in $\mathrm{ml}$ used in titration against Fehling solution.

Non-reducing sugars: The formula to measure non-reducing sugar as previously described (Hortwitz, 1960) is as follows;

Non-reducing sugars (\%) $=0.95 \times$ (Total inverted sugars $\%$ - Reducing sugars \%)

Acidity percent (\%): To determine titratable acidity (TA) of juice was expressed as a percentage and calculated by using the formula given below;

Titratable acidity

$$
=\frac{(\text { Milli }- \text { equivalent factor } 0.0064) \times(\text { volume of titrant }) \times \text { volume of } \mathrm{NaOH}}{m L \text { of Juice } \times \text { volume of aliquot }} \times 100
$$

Where;

Milli-equivalent weight of citric acid $=0.0064$, Total volume $(\mathrm{mL})=30$, Extract juice sample $(\mathrm{mL})=10$ and Volume of aliquot $(\mathrm{mL})=5 \mathrm{~mL}$.

pH: The $\mathrm{pH}$ of each sample was estimated using a digital $\mathrm{pH}$ meter (HANA 8520, Japan).

\section{Statistical analysis}

Statistical software, Statistix 8.1, was used to analyze the data. The significance of treatments was determined using the analysis of variance (ANOVA). The least significant difference (Fisher's protected LSD) test was used to compare the means of the treatments at $P \leq 0.05$ ).

\section{Results and Discussion}

Citrus plants affected with the citrus greening disease were identified, and Iodo starch test was performed on the samples. An aqueous solution of each treatment containing different micronutrients such as Zinc sulfate and Manganese sulfate was sprayed on the whole plant until the runoff to check the effect of micronutrients on citrus greening affected fruits.

\section{Symptomology}

Disease-specific symptoms of citrus greening were observed, as described previously by Polek et al. (2007) and Batool et al. (2007). Mottled leaves were observed on the infected trees and were exhibiting symptoms like Zinc deficiency. Infected fruits were poorly developed and lopsided. The infected fruits remain 


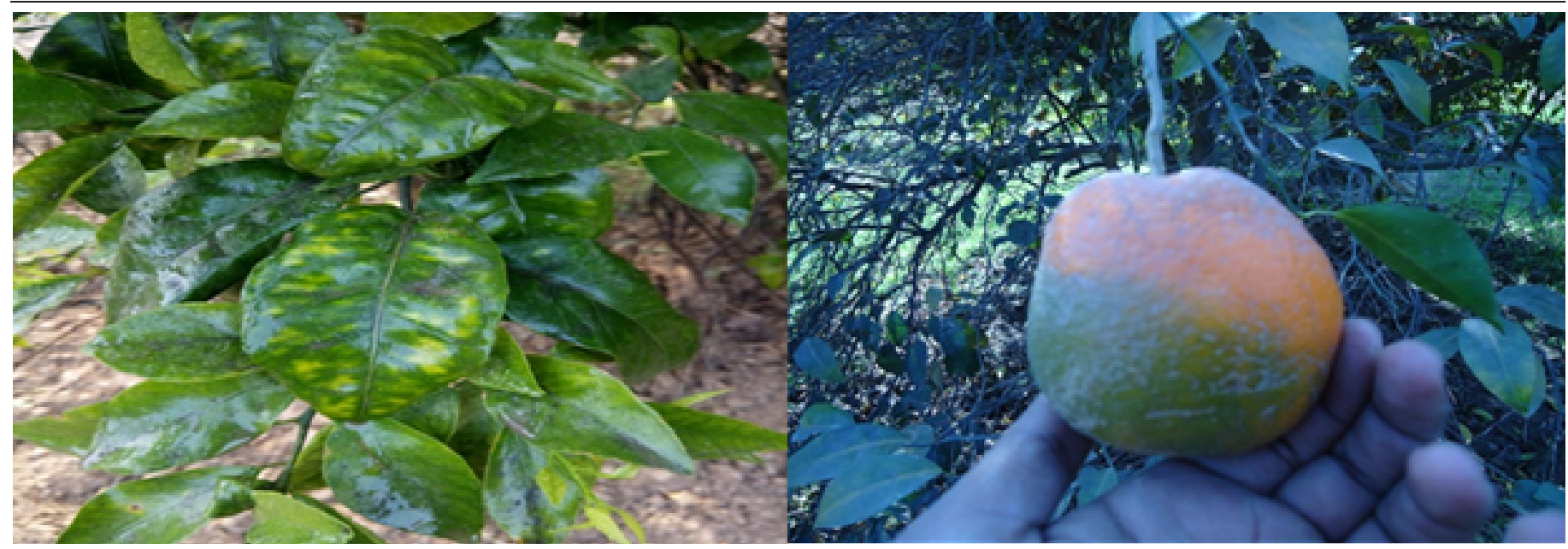

Figure 1: Characteristic symptoms of HLB.

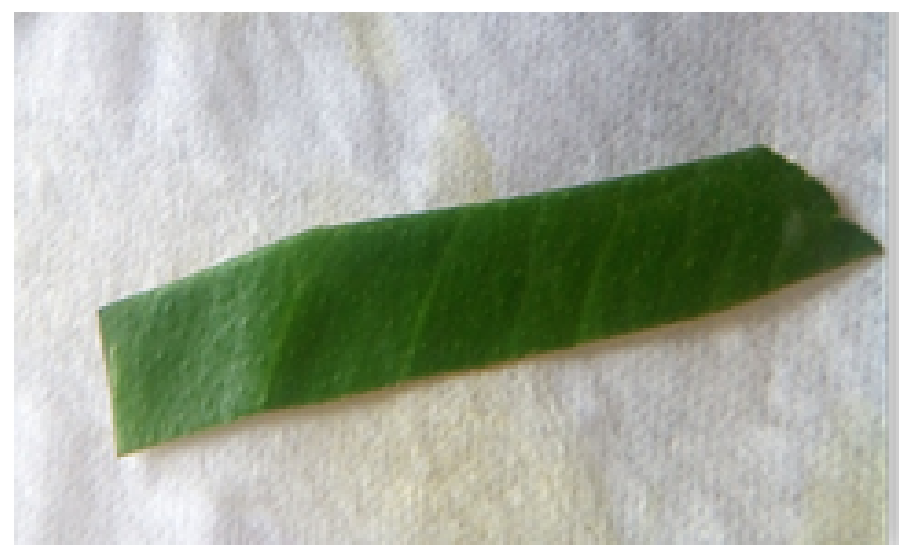

Figure 2: Infected leaves showing very intense dark grey to black color throughout the entire cut surface.

undeveloped and partially or entirely failed in attaining natural orange fruit color (Figure 1).

\section{Iodo starch test}

HLB-positive leaves had a dark grey to black color across the sliced surface. Only a small part of the margins of healthy leaves was discoloured, compared to the edges of HLB positive leaves samples (Figure 2).

\section{Fruit diameter ( $\mathrm{mm}$ ) and fruit weight $(\mathrm{g})$}

The fruits showing HLB disease symptoms were mostly small in size, green in color, underdeveloped, and not properly shaped (Shokrollah, 2011). Fruit diameter is one of the most significant contributors to fruit production in Kinnow as fruit diameter and fruit weight is directly linked. Fruit diameter was significantly enhanced in all the treatments compared to the control (Figure 3A) fruits. Highest fruit diameter was $73.57 \mathrm{~mm}$ in $\mathrm{ZnSO}_{4}(0.75 \mathrm{~g} / \mathrm{L})+\mathrm{MnSO}_{4}(0.75 \mathrm{~g} / \mathrm{L})$ followed by $\mathrm{ZnSO}_{4}(0.25 \mathrm{~g} / \mathrm{L})+\mathrm{MnSO}_{4}(0.25 \mathrm{~g} / \mathrm{L})$ $67.80 \mathrm{~mm}$ and $\mathrm{ZnSO}_{4}(0.50 \mathrm{~g} / \mathrm{L})+\mathrm{MnSO}_{4}(0.50$ $\mathrm{g} / \mathrm{L}) 65.87 \mathrm{~mm}$. However, a minimum fruit diameter was observed in control $(65.18 \mathrm{~mm})$. The maximum diameter of fruit was observed where a foliar spray of two micronutrient $\mathrm{ZnSO}_{4}(0.75 \mathrm{~g} / \mathrm{L})+\mathrm{MnSO}_{4}(0.75$ $\mathrm{g} / \mathrm{L}$ ) was applied, and the least diameter is noticed in control where plants were kept unsprayed. It may be argued that the increase in fruit diameter is due to cell division and enlargement by the application of $\mathrm{Zn}$ and Mn on Kinnow fruits (Shukla, 2011; Salisbury and Ross, 1992). However, $\mathrm{Zn}$ has a vital role in the production of tryptophan, a forerunner in creating indole acetic acid responsible for development and growth (Cakmak et al., 1989). It has been previously reported that Zinc or Boron's foliar spray significantly increased the fruit diameter of mandarin and sweet orange (Razzaq et al., 2013). The current study also supports the findings of Babu and Yadav (2005), who investigated the effects of micronutrients $\left(\mathrm{MgSO}_{4}\right.$, $\mathrm{ZnSO}_{4}$, and $\mathrm{MnSO}_{4}$ ) on fruit quality and found that those nutrients increased the fruit diameter of Kinnow mandarin. Moreover, fruit weight, peel thickness and size of fruit was also increased and this might be due to tryptophan (Cakmak et al., 1989), involved in the development of fruit growth. The micronutrients' treatments improved the fruit weight in comparison with control. Maximum fruit weight was observed in $\mathrm{ZnSO}_{4}(0.75 \mathrm{~g} / \mathrm{L})+\mathrm{MnSO}_{4}(0.75 \mathrm{~g} / \mathrm{L}) 143.00 \mathrm{~g}$ followed by in $\mathrm{ZnSO}_{4}(0.25 \mathrm{~g} / \mathrm{L})+\mathrm{MnSO}_{4}(0.25 \mathrm{~g} / \mathrm{L})$ $139.26 \mathrm{~g}$ and $\mathrm{ZnSO}_{4}(0.50 \mathrm{~g} / \mathrm{L})+\mathrm{MnSO}_{4}(0.50 \mathrm{~g} / \mathrm{L})$ 139.07 g. However, minimum fruit weight was observed in control (132.15 g) (Figure 3B). The maximum fruit weight was measured in $\mathrm{T}_{4}$ followed by $\mathrm{T}_{3}$, $\mathrm{T}_{2}$, and the least fruit weight was noticed in control, where no micronutrient was applied by foliar application. It may be argued that an increase in fruit size is owing to $\mathrm{Zn}$ and $\mathrm{Mn}$ foliar sprays might be ascribed to their role in harmonizing the dietary position of citrus as the increase in fruit weight is due to cell 

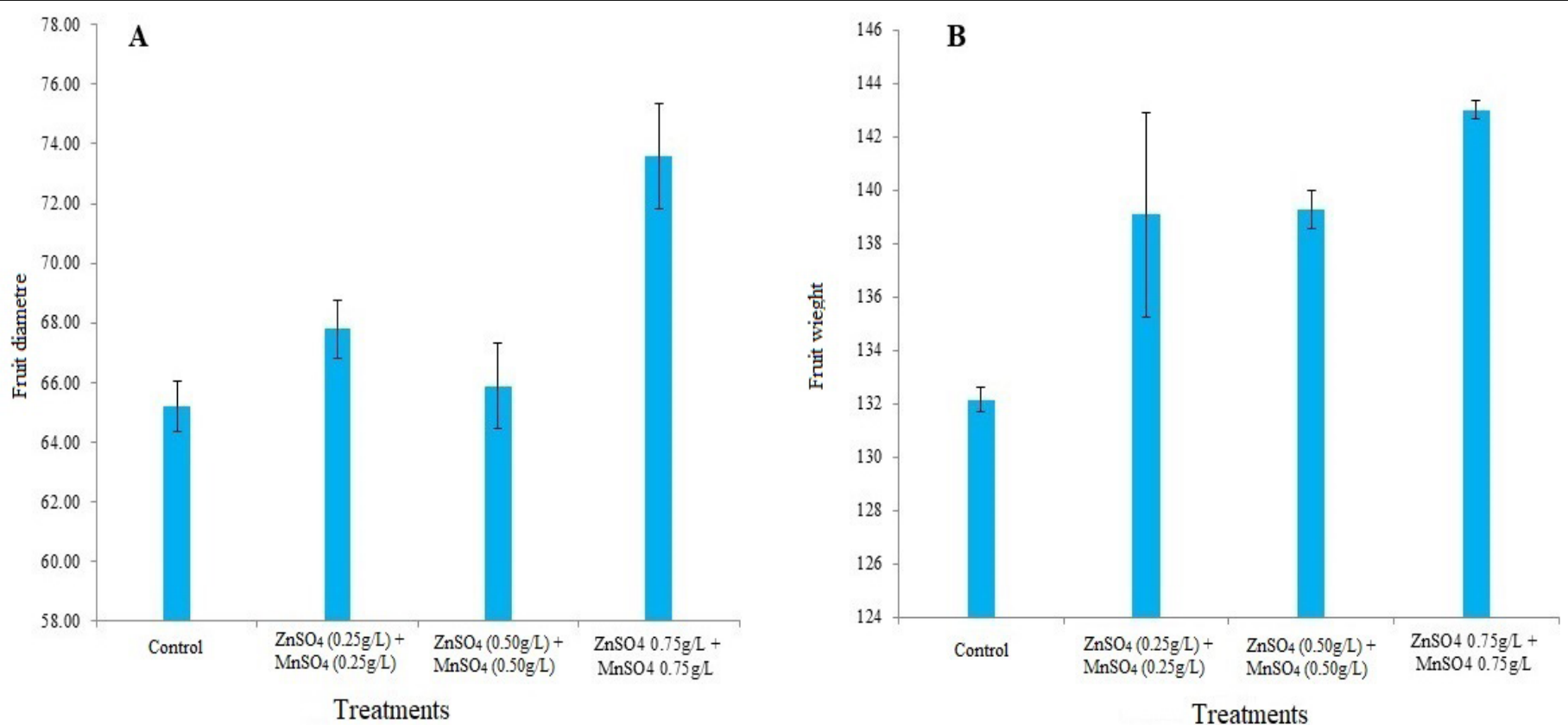

Figure 3: Impact of zinc sulphate $\left(\mathrm{ZnSO}_{4}\right)$ and manganese sulphate $(\mathrm{MnSO})$ treatments on fruit $(A)$ diameter and $(B)$ weight.
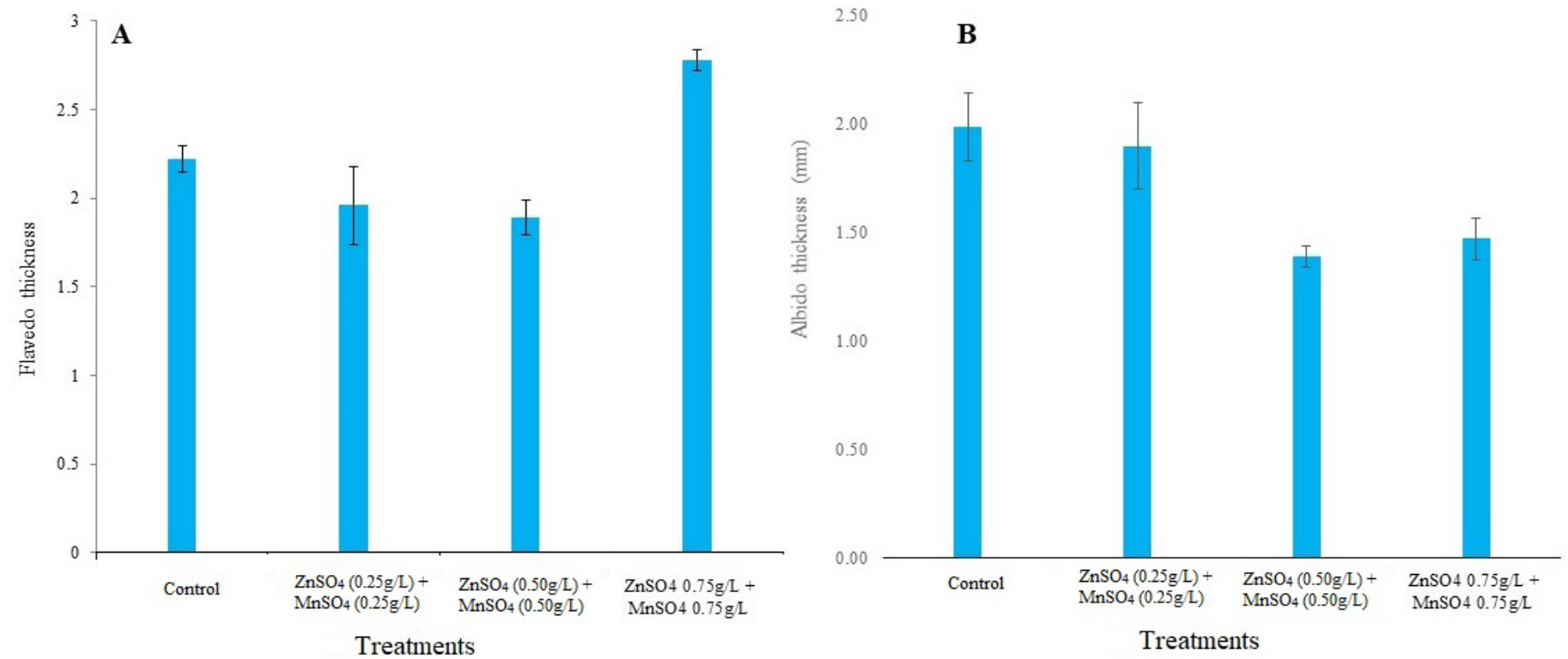

Figure 4: Impact of zinc sulphate $\left(\mathrm{ZnSO}_{4}\right)$ and manganese sulphate $\left(\mathrm{MnSO}_{4}\right)$ treatments on Flavedo (A)and Albedo thickness $(B)$.

division and enlargement by the application of $\mathrm{Zn}$ and $\mathrm{Mn}$ on Kinnow fruits. The above findings were in contrast to the findings of Razzaq et al. (2013) where peel thickness was increased in application of $0.4 \%$ $\mathrm{ZnSO}_{4}$ as compared to control.

\section{Flavedo and albedo thickness ( $\mathrm{mm}$ )}

It was reported that peel thickness expressively improved amongst mandarin-treated fruits diseased by HLB (Shokrollah et al., 2011). Our results contrast with all of the previous findings. It might be due to a cultivar change or a difference in the fruiting stage at which micronutrients have been applied. We found that Zinc sulphate and Manganese sulphate have a highly significant effect on flavedo thickness. In Kin- now fruits, the flavedo thickness was increased due to foliar application of plant growth elicitors (Lee and Kader, 1993). The current study was also supported by the findings of Thomas and Lovatt (2004). Maximum flavedo thickness of fruit was observed $\mathrm{ZnSO}_{4}(0.75 \mathrm{~g} / \mathrm{L})+\mathrm{MnSO}_{4}(0.75 \mathrm{~g} / \mathrm{L}) 2.78 \mathrm{~mm}$ followed by control $(2.22 \mathrm{~mm})$ and $\mathrm{ZnSO}_{4}(0.25 \mathrm{~g} / \mathrm{L})$ $+\mathrm{MnSO}_{4}(0.25 \mathrm{~g} / \mathrm{L}) 1.96 \mathrm{~mm}$. However, minimum flavedo thickness was observed in $\mathrm{ZnSO}_{4}(0.50 \mathrm{~g} / \mathrm{L})$ $+\mathrm{MnSO}_{4}(0.50 \mathrm{~g} / \mathrm{L}) 1.86 \mathrm{~mm}$ (Figure 4A). Maximum value of albedo was noticed in control (1.99 $\mathrm{mm}$ ) as compared to other treatments followed by $\mathrm{ZnSO}_{4}(0.25 \mathrm{~g} / \mathrm{L})+\mathrm{MnSO}_{4}(0.25 \mathrm{~g} / \mathrm{L}) 1.90 \mathrm{~mm}$ and $\mathrm{ZnSO}_{4}(0.75 \mathrm{~g} / \mathrm{L})+\mathrm{MnSO}_{4}(0.75 \mathrm{~g} / \mathrm{L}) 1.47 \mathrm{~mm}$. As well as a minimum value of albedo was observed in March 2022 | Volume 38 | Issue 1 | Page 364 

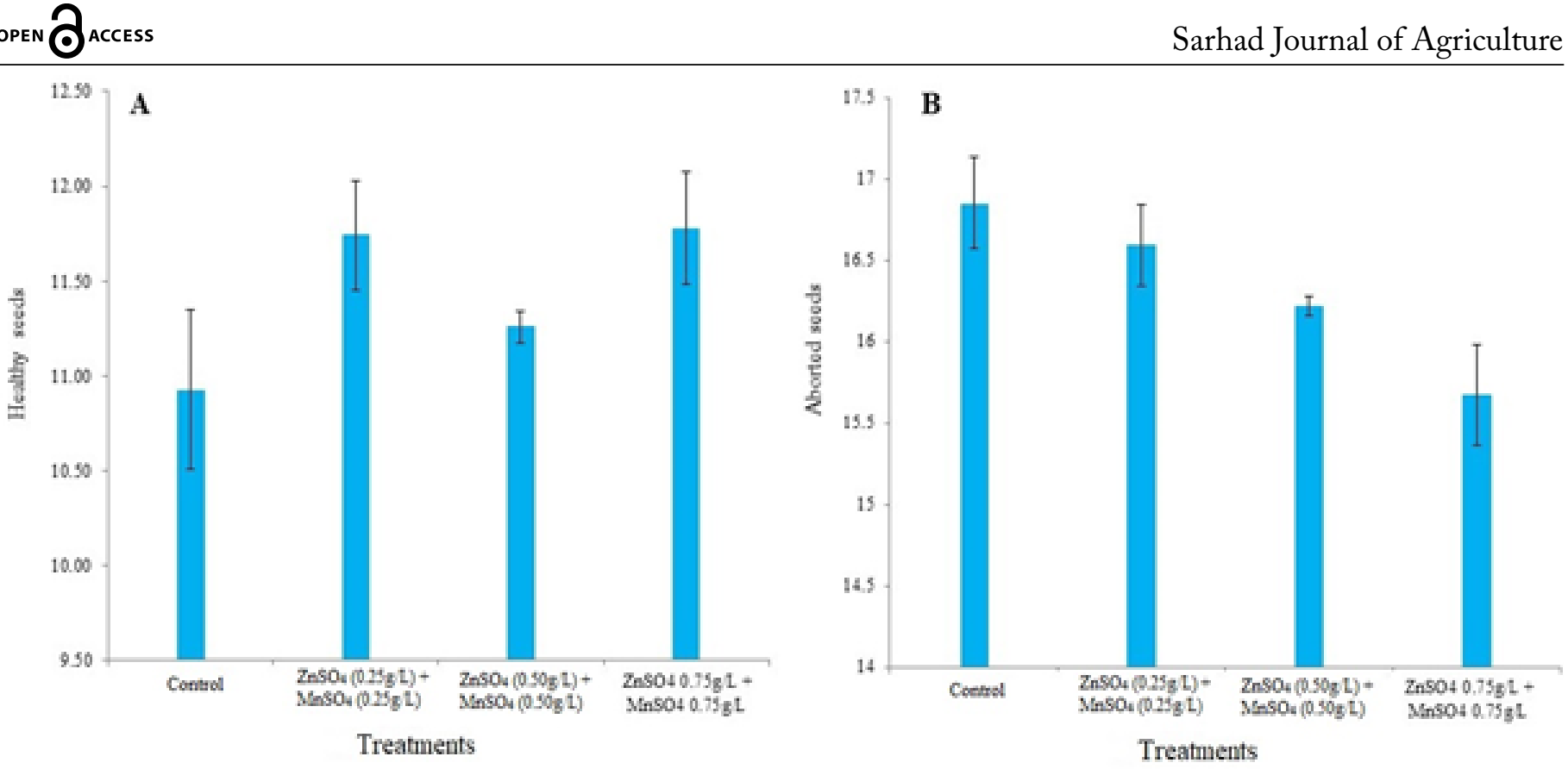

Figure 5: Impact of zinc sulphate $\left(\mathrm{ZnSO}_{4}\right)$ and manganese sulphate $\left(\mathrm{MnSO}_{4}\right)$ treatments on healthy $(A)$ and aborted $(B)$ seeds.

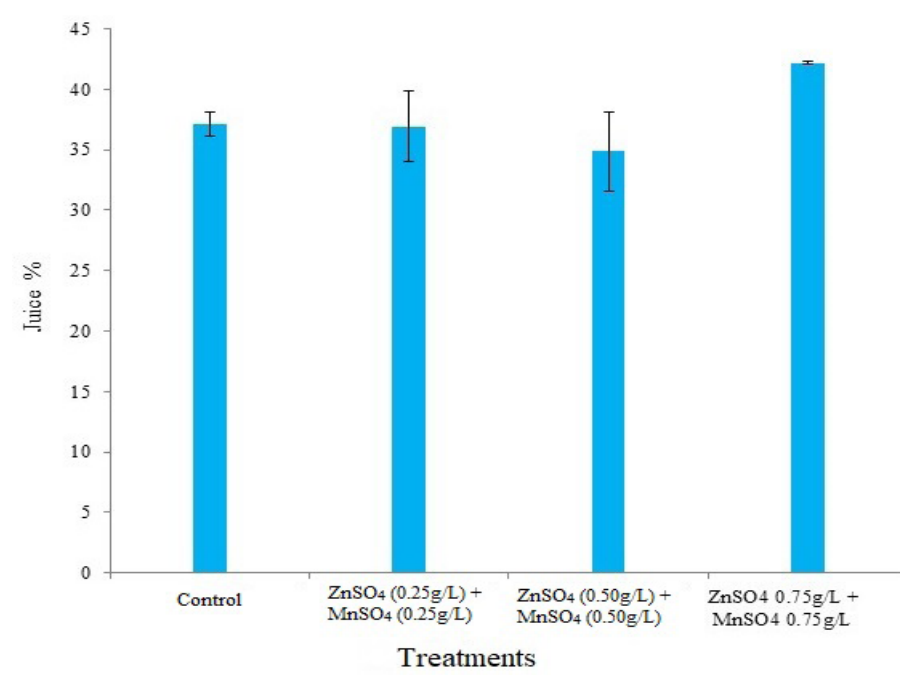

Figure 6: Impact of zinc sulphate $\left(\mathrm{ZnSO}_{4}\right)$ and manganese sulphate $\left(\mathrm{MnSO}_{4}\right)$ treatments on juice \%.

$\mathrm{ZnSO}_{4}(0.50 \mathrm{~g} / \mathrm{L})+\mathrm{MnSO}_{4}(0.50 \mathrm{~g} / \mathrm{L}) 1.39 \mathrm{~mm}$ as compared to other treatments (Figure $4 \mathrm{~B}$ ).

\section{Healthy and aborted seeds}

Zinc has an important micro-nutrient for synthesis of protein, production of seed and rate of plants' maturity (Swietlik, 2002). However, we found that micronutrients did not significantly affect healthy seeds. Maximum number of healthy seeds of fruit was observed in $\mathrm{ZnSO}_{4}(0.75 \mathrm{~g} / \mathrm{L})+\mathrm{MnSO}_{4}(0.75$ $\mathrm{g} / \mathrm{L}) 11.78$ seeds followed by in $\mathrm{ZnSO}_{4}(0.25 \mathrm{~g} / \mathrm{L})+$ $\mathrm{MnSO}_{4}(0.25 \mathrm{~g} / \mathrm{L}) 11.74$ seeds and in $\mathrm{ZnSO}_{4}(0.50$ $\mathrm{g} / \mathrm{L})+\mathrm{MnSO}_{4}(0.50 \mathrm{~g} / \mathrm{L}) 11.26$ seeds. However, a minimum number of healthy seeds were observed in the control (10.93 seeds) (Figure 5A). Seed abortion is common in HLB-infected citrus trees (Batool et al., 2007). HLB infected fruit develop poor color, smaller size, and mostly contain partially or completely aborted seeds, and HLB infected fruit has few numbers of total seeds per fruit (Albrecht and Bowman, 2008). Aborted seeds were non-significantly influenced by applying Zinc sulphate $\left(\mathrm{ZnSO}_{4}\right)$ and Manganese sulphate $\left(\mathrm{MnSO}_{4}\right)$. Maximum number of aborted seed were observed in control (16.85 seeds) followed by $\mathrm{ZnSO}_{4}(0.25 \mathrm{~g} / \mathrm{L})+\mathrm{MnSO}_{4}(0.25 \mathrm{~g} / \mathrm{L}) 16.59$ aborted seeds and $\mathrm{ZnSO}_{4}(0.50 \mathrm{~g} / \mathrm{L})+\mathrm{MnSO}_{4}(0.50 \mathrm{~g} / \mathrm{L})$ 16.22 aborted seeds. However, the least number of aborted seeds were noticed in $\mathrm{ZnSO}_{4}(0.75 \mathrm{~g} / \mathrm{L})+$ $\mathrm{MnSO}_{4}(0.75 \mathrm{~g} / \mathrm{L}) 15.67$ aborted seeds (Figure 5B). Our results support the findings of Razzaq et al. (2013) that fruit picked from those trees that were foliar fertilized with $\mathrm{Zn}$ have not shown any substantial variation in the weight of seed, the quantity of vigorous, and the number of aborted seeds.

\section{Juice percentage (\%)}

Maximum Juice \% of fruit was observed in $\mathrm{ZnSO}_{4}$ $(0.75 \mathrm{~g} / \mathrm{L})+\mathrm{MnSO}_{4}(0.75 \mathrm{~g} / \mathrm{L}) 42.18 \%$ followed by control (37.11\%) and $\mathrm{ZnSO}_{4}(0.25 \mathrm{~g} / \mathrm{L})+\mathrm{MnSO}_{4}$ $(0.25 \mathrm{~g} / \mathrm{L}) 36.86 \%$. However, minimum juice $\%$ was observed in $\mathrm{ZnSO}_{4}(0.50 \mathrm{~g} / \mathrm{L})+\mathrm{MnSO}_{4}(0.50 \mathrm{~g} / \mathrm{L})$ $34.86 \%$ (Figure 6). We found that micronutrients did not have a significant effect on juice. The foliar application of different nutrients like magnesium, copper, zinc, iron and boron increased the quantity and quality of juice (Suresh et al., 2018).

\section{Total soluble solids (TSS)}

The TTS measurement is a significant factor for the superiority of citrus fruits. High TSS means virtuous March 2022 | Volume 38 | Issue 1 | Page 365 

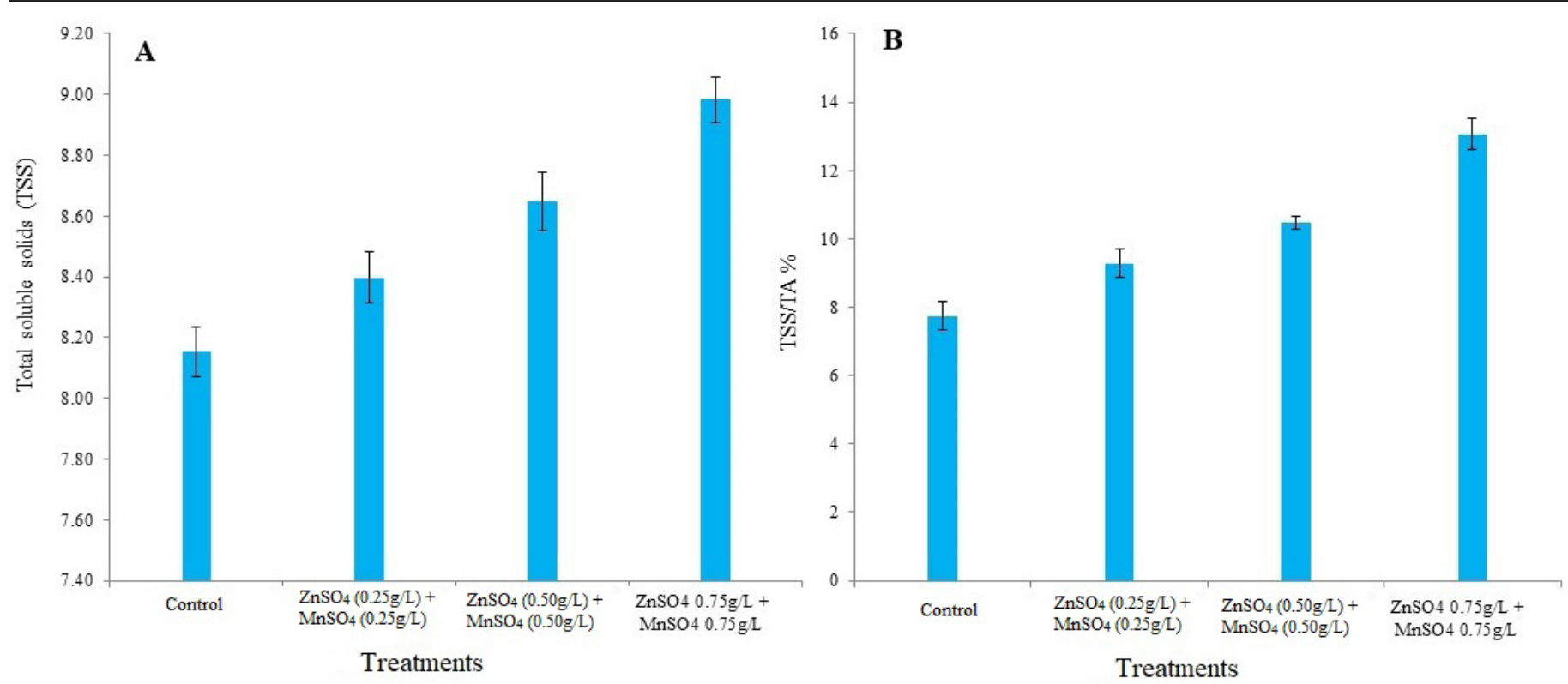

Figure 7: Impact of zinc sulphate ( $\mathrm{ZnSO}$ ) and manganese sulphate (MnSO) treatments on TSS (A) and TA Ratio (B).

superiority fruit and vice versa. Maximum TSS of fruit was observed in $\mathrm{ZnSO}_{4}(0.75 \mathrm{~g} / \mathrm{L})+\mathrm{MnSO}_{4}$ $(0.75 \mathrm{~g} / \mathrm{L}) 8.98$ Brix followed by $\mathrm{ZnSO}_{4}(0.50 \mathrm{~g} / \mathrm{L})^{4}$ $+\mathrm{MnSO}_{4}(0.50 \mathrm{~g} / \mathrm{L}) 8.65 \mathrm{Brix}$ and in $\mathrm{ZnSO}_{4}(0.25$ $\mathrm{g} / \mathrm{L})+\mathrm{MnSO}_{4}(0.25 \mathrm{~g} / \mathrm{L})$ 8.40brix. However, minimum TSS was observed in the control treatment (8.15 Brix) (Figure 7A). As we compare our results, TSS significantly increased by the foliar spray of $\mathrm{ZnSO}_{4}$ and $\mathrm{MnSO}_{4}$. Our results support the results of Srivastava and Gupta (1996).

\section{TSS/TA Ratio}

The rise in TSS /TA ratio using foliar Zinc sulphate might be credited to their properties on different enzymes responsible for developing sugars, proteins, and acids (Srivastava and Gupta, 1996). Maximum TSS/TA of fruit was observed in $\mathrm{ZnSO}_{4}(0.75 \mathrm{~g} / \mathrm{L})$ $+\mathrm{MnSO}_{4}(0.75 \mathrm{~g} / \mathrm{L}) 13.07$ followed by $\mathrm{ZnSO}_{4}(0.50$ $\mathrm{g} / \mathrm{L})+\mathrm{MnSO}_{4}(0.50 \mathrm{~g} / \mathrm{L}) 10.47 \mathrm{ZnSO}_{4}(0.25 \mathrm{~g} / \mathrm{L})+$ $\mathrm{MnSO}_{4}(0.25 \mathrm{~g} / \mathrm{L})$ 9.27. However, minimum TSS/ TA was observed in the control treatment (7.75) (Figure $7 \mathrm{~B}$ ). The maximum TSS/TA was observed in $\mathrm{T}_{4}$, and the least was observed in the control treatment. The following findings justify Dawood et al. (2001) findings that TSS /TA proportion could be improved using Zinc sulphate in mandarin.

\section{Ascorbic acid}

Ascorbic acid (vitamin C) substance in fruit differs in fixation for different citrus species. Ascorbic acid is influenced by the ecological elements, time of fruit collecting, plant vigour, the plant, and micronutrients and PGRs (Iglesias, 2007). Maximum ascorbic acid of fruit was observed in $\mathrm{ZnSO}_{4}(0.75 \mathrm{~g} / \mathrm{L})+\mathrm{MnSO}_{4}$ $(0.75 \mathrm{~g} / \mathrm{L}) 37.14 \%$, followed by $\mathrm{ZnSO}_{4}(0.25 \mathrm{~g} / \mathrm{L})+$ $\mathrm{MnSO}_{4}(0.25 \mathrm{~g} / \mathrm{L}) 36.12 \%$ and in control $(34.28 \%)$. However, minimum ascorbic acid was observed in $\mathrm{ZnSO}_{4}(0.50 \mathrm{~g} / \mathrm{L})+\mathrm{MnSO}_{4}(0.50 \mathrm{~g} / \mathrm{L}) 33.06 \%$ (Figure 8A). Our findings justify El-Menshawi et al. (1997) that foliar application of $\mathrm{Zn}$ raised the ascorbic acid contents in citrus.

\section{Total sugars}

Total sugars were non-significantly influenced by applying Zinc sulphate $\left(\mathrm{ZnSO}_{4}\right)$ and Manganese sulphate $\left(\mathrm{MnSO}_{4}\right)$. Maximum total sugars of fruit were observed in control (9.80\%), followed by $\mathrm{ZnSO}_{4}$ $(0.75 \mathrm{~g} / \mathrm{L})+\mathrm{MnSO}_{4}(0.75 \mathrm{~g} / \mathrm{L}) 9.52 \%$ and $\mathrm{ZnSO}_{4}$ $(0.25 \mathrm{~g} / \mathrm{L})+\mathrm{MnSO}_{4}(0.25 \mathrm{~g} / \mathrm{L})(9.48 \%)$. However, minimum total sugar was observed in $\mathrm{ZnSO}_{4}(0.50$ $\mathrm{g} / \mathrm{L})+\mathrm{MnSO}_{4}(0.50 \mathrm{~g} / \mathrm{L}) 8.98 \%$ (Figure 8B). Our results regarding total sugars were non-significantly influenced by the application of $\mathrm{Zinc}$ sulphate $\left(\mathrm{ZnSO}_{4}\right)$ and Manganese sulphate $\left(\mathrm{MnSO}_{4}\right)$. Our results were found in contrast to the results of Babu and Yadav, (2005), who reported that $\mathrm{Zn}$ and $\mathrm{Mn}, \mathrm{Mg}$ and B, improved the total sugars \% in Khasi mandarin. The total and non-reducing sugars have a role in starch metabolism and biochemical reactions in plants (Alloway, 2008).

\section{Reducing sugars}

Reducing sugars were non-significantly influenced by applying Zinc sulphate $\left(\mathrm{ZnSO}_{4}\right)$ and Manganese sulphate $\left(\mathrm{MnSO}_{4}\right)$. Maximum reducing sugars of fruit was observed in control (5.58\%), followed 


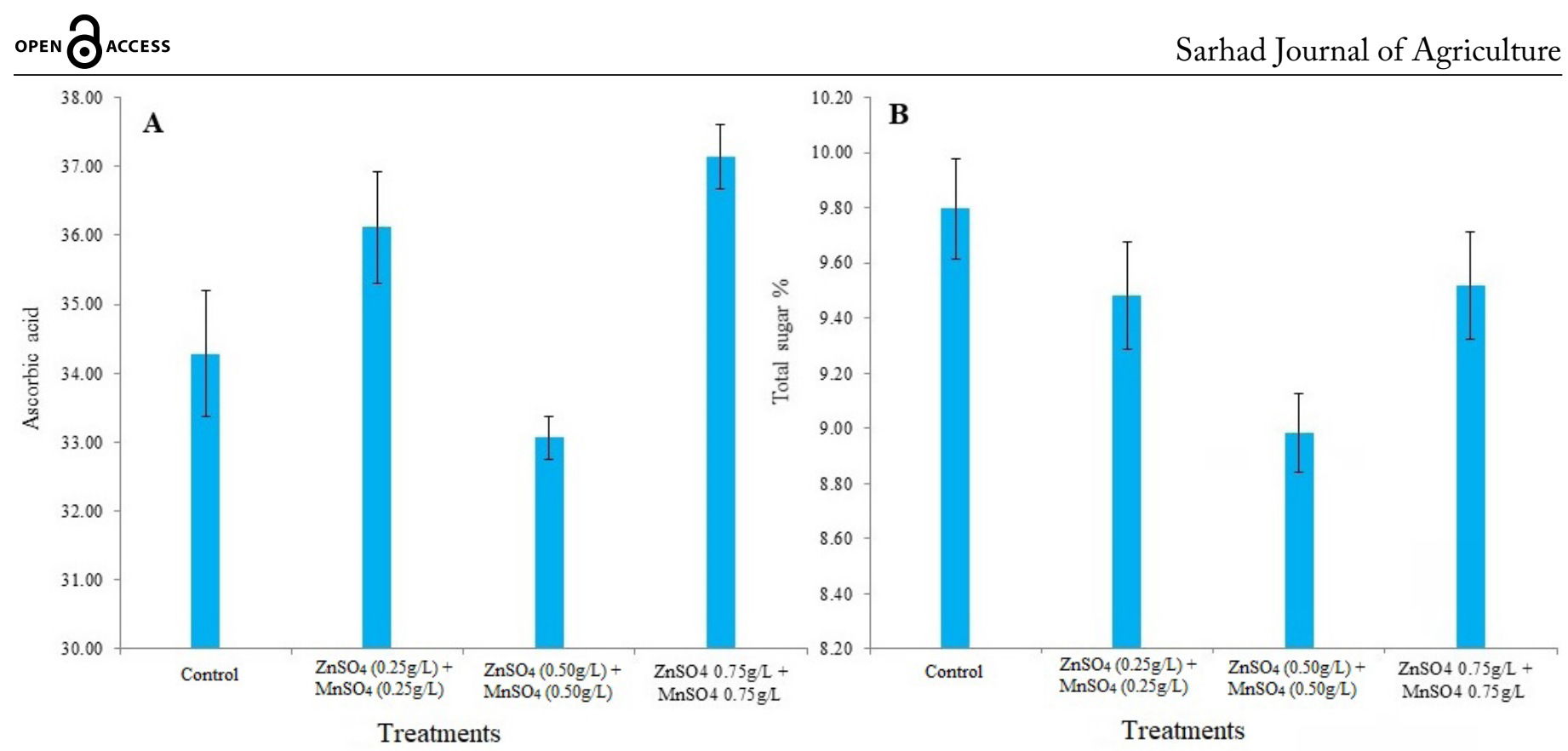

Figure 8: Impact of zinc sulphate $\left(\mathrm{ZnSO}_{4}\right)$ and manganese sulphate $\left(\mathrm{MnSO} \mathrm{O}_{4}\right)$ treatments on ascorbic acid $(A)$ and Total sugars $(B)$.

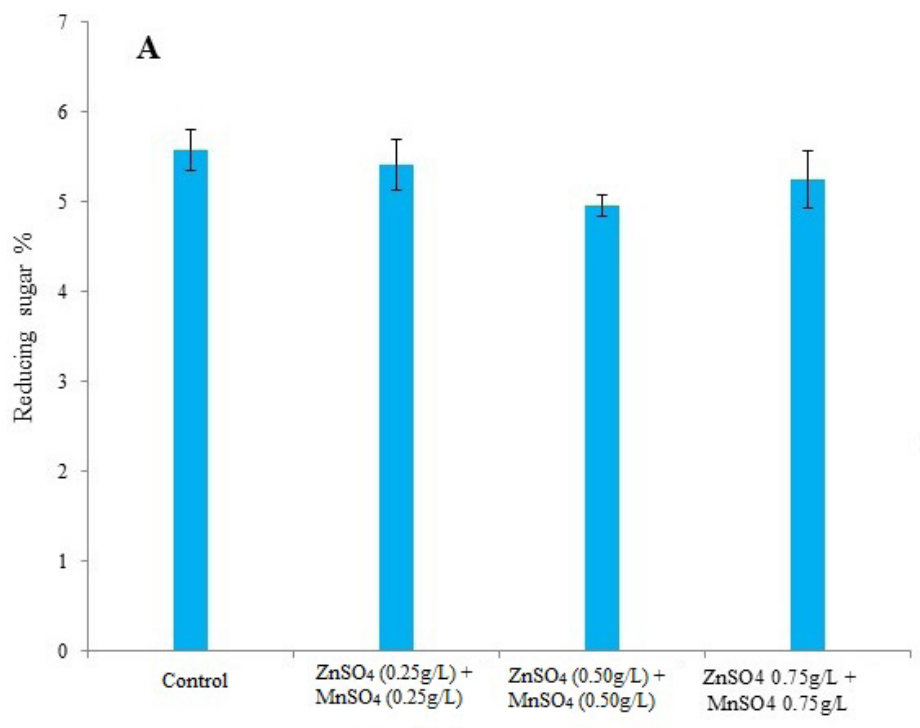

Treatments

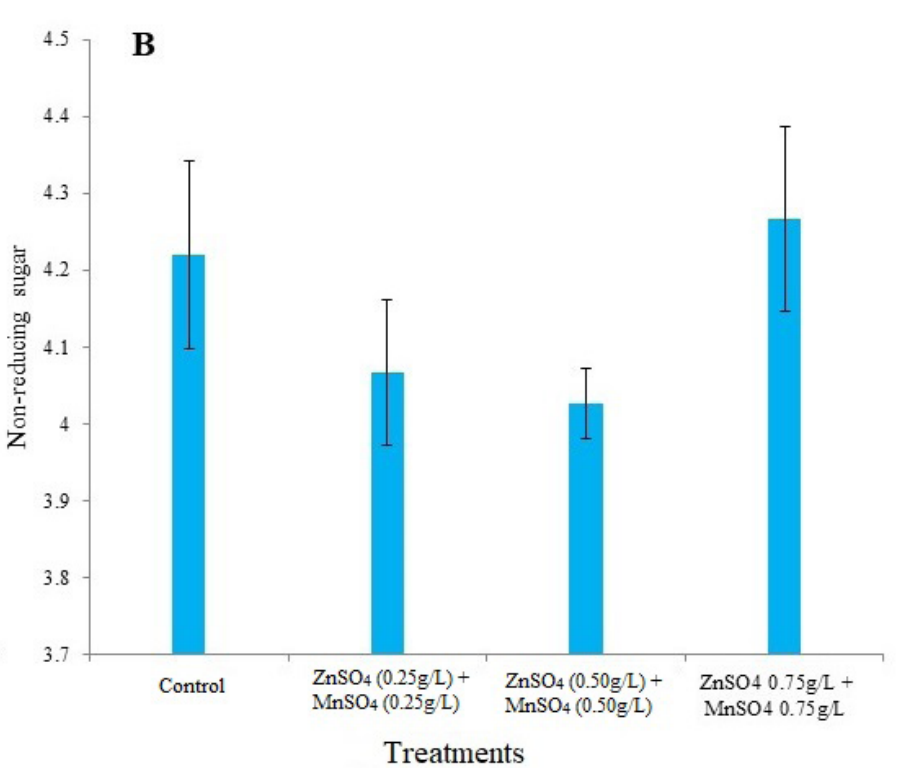

Treatments

Figure 9: Impact of zinc sulphate $\left(\mathrm{ZnSO}_{4}\right)$ and manganese sulphate $\left(\mathrm{MnSO}_{4}\right)$ treatments on reducing $(A)$ and non-reducing $(B)$ sugar.

by in $\mathrm{ZnSO}_{4}(0.25 \mathrm{~g} / \mathrm{L})+\mathrm{MnSO}_{4}(0.25 \mathrm{~g} / \mathrm{L}) 5.42 \%$ and $\mathrm{ZnSO}_{4}(0.75 \mathrm{~g} / \mathrm{L})+\mathrm{MnSO}_{4}(0.75 \mathrm{~g} / \mathrm{L}) 5.25 \%$. However, minimum reducing sugars was observed in $\mathrm{ZnSO}_{4}(0.50 \mathrm{~g} / \mathrm{L})+\mathrm{MnSO}_{4}(0.50 \mathrm{~g} / \mathrm{L}) 4.95 \%$ (Figure 9A). Our results justify the results of Tariq et al. (2007). They resulted that in sweet orange and mandarin, the application of $\mathrm{Mn}, \mathrm{Zn}$, and B through foliar spray did not reduce sugars.

\section{Non-Reducing sugars}

Non-reducing sugars were non-significantly influenced by applying Zinc sulphate $\left(\mathrm{ZnSO}_{4}\right)$ and Manganese sulphate $\left(\mathrm{MnSO}_{4}\right)$. Maximum non-reducing sugars of fruit was observed in $\mathrm{ZnSO}_{4}(0.75 \mathrm{~g} / \mathrm{L})$ + $\mathrm{MnSO}_{4}(0.75 \mathrm{~g} / \mathrm{L})$ 4.27\%, followed by control
(4.22\%) and $\mathrm{ZnSO}_{4}(0.25 \mathrm{~g} / \mathrm{L})+\mathrm{MnSO}_{4}(0.25 \mathrm{~g} / \mathrm{L})$ $4.07 \%$. However, minimum non-reducing sugars was observed in $\mathrm{ZnSO}_{4}(0.50 \mathrm{~g} / \mathrm{L})+\mathrm{MnSO}_{4}(0.50 \mathrm{~g} / \mathrm{L})$ $4.03 \%$ (Figure 9B). Our results revealed that non-reducing sugars were non-significantly increaed due to foliar application of $\mathrm{ZnSO}_{4}$ and $\mathrm{MnSO}_{4}$. Our results were in accordance with Tariq et al. (2007), who observed the same trend for reducing and non-reducing sugar after the micro-nutrients application.

\section{Acidity percent (\%)}

An investigation of HLB contaminated and non-infected Kinnow mandarins discovered low soluble solids and high acidity in HLB infected fruits as compared to healthy (Kapur et al., 1978). Maximum 

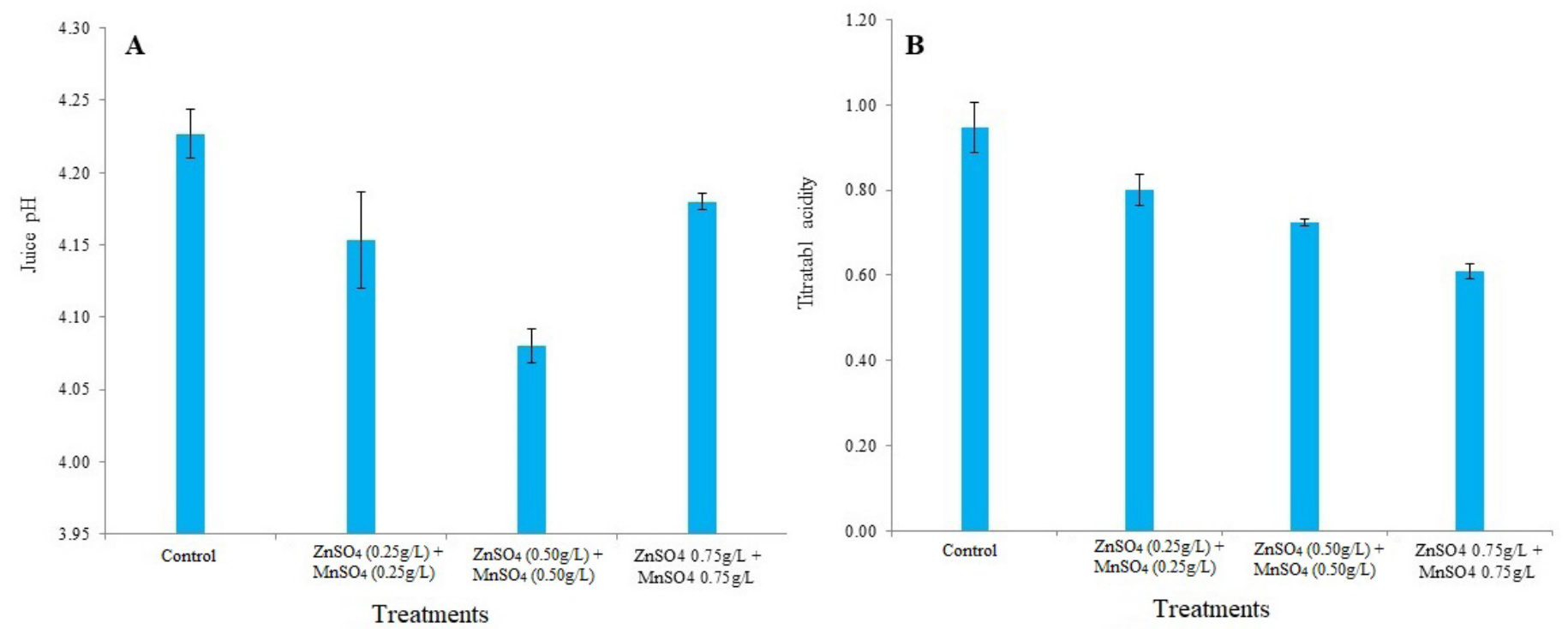

Figure 10: Impact of zinc sulphate $\left(\mathrm{ZnSO}\right.$ ) and manganese sulphate $\left(\mathrm{MnSO}_{\uparrow}\right)$ treatments on Juice $\mathrm{pH}(A)$ and Acidity percent (\%) (B).

acidity (\%) of fruit was observed in control (0.95\%) followed by $\mathrm{ZnSO}_{4}(0.25 \mathrm{~g} / \mathrm{L})+\mathrm{MnSO}_{4}(0.25 \mathrm{~g} / \mathrm{L})$ $0.80 \%$ and $\mathrm{ZnSO}_{4}(0.50 \mathrm{~g} / \mathrm{L})+\mathrm{MnSO}_{4}(0.50 \mathrm{~g} / \mathrm{L})$ $0.72 \%$. However, minimum acidity (\%) was observed in $\mathrm{ZnSO}_{4}(0.75 \mathrm{~g} / \mathrm{L})+\mathrm{MnSO}_{4}(0.75 \mathrm{~g} / \mathrm{L}) 0.61 \%$ (Figure 10A). Our results showed that titratable acidity significantly decreases by the foliar spray of micronutrients. Ilame and Singh (2018) observed similar findings that minimum acidity was noticed with Zinc alone combined with growth regulators.

\section{$p H$}

Maximum $\mathrm{pH}$ of fruit was observed in $\mathrm{ZnSO}_{4}(0.75$ $\mathrm{g} / \mathrm{L})+\mathrm{MnSO}_{4}(0.75 \mathrm{~g} / \mathrm{L}) 4.18$, followed by control (4.23) and $\mathrm{ZnSO}_{4}(0.25 \mathrm{~g} / \mathrm{L})+\mathrm{MnSO}_{4}(0.25 \mathrm{~g} / \mathrm{L})$ 4.15. However, minimum $\mathrm{pH}$ was observed in $\mathrm{ZnSO}_{4}$ $(0.50 \mathrm{~g} / \mathrm{L})+\left(\mathrm{MnSO}_{4} 0.50 \mathrm{~g} / \mathrm{L}\right) 4.08$ (Figure 10B) Our results micronutrients have a significant effect on $\mathrm{pH}$. Our results also supported by the findings of Razzaq et al. (2013), reported that foliar $\mathrm{Zn}$ increased fruit production and fruit quality of kinnow mandarin. Moreover, $\mathrm{Zn}$ had an impact on vitamin $\mathrm{C}$ and pH (Ashraf et al., 2013).

\section{Conclusions and Recommendations}

In conclusion, foliar spray of $\mathrm{ZnSO}_{4}$ and $\mathrm{MnSO}_{4}$ on the HLB infected fruits significantly increased the fruit diameter, fruit weight, total soluble solids, flavedo thickness, ascorbic acids, juice percentages, TSS/ TA ratio and titratable acidity. Among the treatments, the treatment $(0.75 \mathrm{~g} / \mathrm{L})$ was the best performing treatment in increasing these parameters. However, reducing and non-reducing sugars were not signifi- cantly influenced. Moreover, research is required to investigate how effectively Zinc sulphate and Manganese sulphate, as well as other micro and macronutrients, improve the quality of citrus greening diseased Kinnow mandarin fruit at different doses and times of application.

\section{Acknowledgments}

The authors are thankful to ORIC-SU for financial support under a project entitled, "Monitoring of devastating effects of Citrus greening disease (CGD) in declining orchards of Sargodha and its management through micronutrients to help citrus industry" in the Department of Plant Pathology, University of Sargodha to complete this part of the research.

\section{Novelty Statement}

This is the first time that the application of micronutrients enhances the quality of Kinnow mandarin infected by greening diseases.

\section{Author's Contribution}

Zahoor Hussain: Designed the research work and supervised the research.

Yasir Iftikhar: Co-supervised the current research work

Zia Saleem: Executed the research work.

Umer Naseer: Helped in laying out research work.

Mustansar Mubeen: Helped to arranging the data for state.

Muhammad Luqman: Edited and proofread the 
manuscript.

Raheel Anwar: Helped in analysis of data collection of references.

Faheeem Khadija: Contributed in description and arranging of manuscript.

Aqleem Abbas: Arranged the manuscript according to journal.

\section{Conflict of interest}

The authors have declared no conflict of interest.

\section{References}

Akhtar, M.A. and I. Ahmad. 1999. Incidence of citrus greening in Pakistan. Pak J. Phytopathol., 11: $1-5$.

Albrecht, U. and K.D. Bowman. 2008. Gene expression in citrus sinensis (L) Osbeck following infection with bacterial pathogen liberibacter asiaticus causing Huanglongbing in Florida. Plant Sci., 175: 291-306. https://doi.org/10.1016/j. plantsci.2008.05.001

Alloway, B.J. 2008. Zinc in soils and crop nutrition. $2^{\text {nd }}$ Edition, IZA and IFA, Brussels, Belgium and Paris, France.

Ashraf, M.Y., F. Hussain, M. Ashraf, J. Akhter and G. Ebert. 2013. Modulation in yield and juice quality characteristics of citrus fruit from trees supplied with Zinc and potassium foliarly. J. Plant Nutr., 36: 1996-2012. https://doi.org/10. 1080/01904167.2013.808668

Babu, K.D. and D.S. Yadav. 2005. Foliar spray of micronutrients for yield and quality improvement in Khasi mandarin (Citrus reticulata Blanco.). Indian J. Hortic., 62: 280-281.

Bassanezi, R.B., L.H. Montesino, M.C.G. Gasparato, A.B. Filho and L. Amorim. 2011. Yield loss caused by Huanglongbing in different sweet orange cultivars in Brazil. Eur. J. Plant Pathol., 130: 577-586. https://doi.org/10.1007/ s10658-011-9779-1

Batool, A., Y. Iftikhar, S.M. Mughal, M.M. Khan, M.J. Jaskani, M. Abbas and I.A. Khan. 2007. Citrus greening disease: a major cause of citrus decline in the world: a review. Hortic. Sci., 34(4): 159-166. https://doi. org/10.17221/1897-HORTSCI

Bové, J.M. 2006. Huanglongbing: a destructive, newly-emerging, century-old disease of citrus. J. Plant Pathol., 23: 7-37.

Cakmak, I., H. Marschner and F. Bangerth. 1989.
Effect of Zinc nutrition status on growth, protein metabolism and level of indole-3 acetic acid and other phytohormones in bean ( $\mathrm{Pha}-$ seolus vulgaris L.). J. Exp. Bot., 40: 405-415. https://doi.org/10.1093/jxb/40.3.405

Chohan, S.N., R. Qamar, I. Sadiq, M. Azam, P. Holford and A. Beattie. 2007. Molecular evidence for the presence of Huanglongbing in Pakistan. Australas. Plant Dis. Notes., 2(1): 3738. https://doi.org/10.1071/DN07019

Cochran, L.C. 1976. The occurrence of greening disease in Pakistan. In International Organization of Citrus Virologists Conference Proceedings (1957-2010):7(7). https://doi. org/10.5070/C54FN7W4RP

Dawood, S.A., M.S. Meligy and M.M. El-Hamady. 2001. Influence of Zinc sulfate application on tree leaf and fruit characters of three young citrus varieties grown on slightly alkaline soil. Ann. Agric. Sci. Moshtohor., 39: 433-447.

Deng, X., Z. Huang, Z. Zheng, Y. Lan and F. Dai. 2019. Field detection and classification of citrus Huanglongbing based on hyperspectral reflectance. Comput. Electron. Agric., 167: 105006. https://doi.org/10.1016/j.compag.2019.105006

Elizabeth, E., K.E. Godfrey, M.E. Rogers, C.C. Childers and P.A. Stansly. 2005. Asian citrus psyllid. Division of Agriculture and Natural Resources. Riverside, University of California, USA.

El-Menshawi, E.A., H.M. Sinble and H.A. Ismail. 1997. Effect of different Zinc, Manganese and forms on yield and fruit quality of Balady mandarin tree. J. Agric. Sci., 22: 2333-2340.

Giles, F. 2011. Daring to be different. Fla. Grow., 104(6): 8e10.

Ha, P.T., R. He., N. Killiny., J.K. Brown., A.O. David., R. Gang and H. Beyenal. 2019. Hostfree biofilm culture of "Candidatus Liberibacter asiaticus," the bacterium associated with Huanglongbing. Biofilim, 1, 1-7. https://doi. org/10.1016/j.bioflm.2019.100005

Hortwitz, W., 1960. Official Methods of Analysis, $8^{\text {th }}$ ed. Associates of official Agric. Chemists Inc. Washington D.C. USA.

Iftikhar, Y., F. Bakhtawar, I. Hussain, A. Sajid, M. Mubeen, M. Ahmad, Zeshan, M.A. Sohail, N. Fatima, M. Umer and S. Iqbal. 2020. Detection of Spiroplasma citri causing citrus stubborn disease in Sargodha, Pakistan. Int. J. Bot. Stud- 
ies., 5(3): 481-485.

Iftikhar, Y., S. Rauf, U. Shahzad and M.A. Zahid. 2016. Huanglongbing: Pathogen detection system for integrated disease management.A review. J. Saudi Soc. Agric. Sci., 15(1): 1-11. https://doi.org/10.1016/j.jssas.2014.04.006

Iglesias, D.J., M. Cercos, J.M. Colmenero-Flores, M.A. Naranjo, G. Rios, E. Carrera, O. Ruiz-Rivero, I. Lliso, R. Morillon, F.R. Tadeo and M. Talon. 2007. Physiology of citrus fruiting. Braz.J. Plant Physiol., 19: 333-362. https:// doi.org/10.1590/S1677-04202007000400006

Ilame, S.A. and S.V. Singh. 2018. Physico-chemical properties of ultra-filtered kinnow (mandarin) fruit juice. J. Food Sci. Technol., 55(6): 2189-2196. https://doi.org/10.1007/s13197018-3136-8

Kapur S.P., S.K. Kapoor, S.S. Cheema and R.S. Dhillon. 1978. Effect of greening disease on tree and fruit characters of Kinnow mandarin. Punjab Hortic. J., 18:176-9.

Lee, S.K. and A.A. Kader. 1993. Pre-harvest and postharvest factors influencing vitamin $\mathrm{C}$ content of horticultural crops. Postharvest Biol. Technol.,20: 207-220.https://doi.org/10.1016/ S0925-5214(00)00133-2

Martini, X., A. Hoyte, A. Mafra-Neto, A.A. Aksenov, C.E. Davis and L.L. Stelinski. 2020. Progress toward an attract-and-kill device for Asian citrus psyllid (Hemiptera: Liviidae) using volatile signatures of citrus infected with Huanglongbing as the attractant. J. Insect Sci., 20(6): 25. https://doi.org/10.1093/jisesa/ieaa126

Polek, M., G. Vidalakis and K. Godfrey. 2007. Citrus Bacterial Canker Disease and Huanglongbing (Citrus Greening). Division of Agriculture and Natural Resources. Riverside, University of California, USA. https://doi.org/10.3733/ ucanr. 8218

Razzaq, K.A., S. Khan, A.U. Malik, M. Shahid and S. Ullah. 2013. Foliar application of Zinc influences the leaf mineral status, vegetative and reproductive growth, and yield and fruit quality of 'KINNOW' mandarin. J. Plant Nutr., 36: 1479-1495. https://doi.org/10.1080/01904167 .2013 .785567

Ruck, J.A., 1961. Chemical Methods for Analysis of Fruits and Vegetables. Department of Agriculture, Research Station Summerland, Research Branch Canada.

Saifullah, I. Haq, Y. Iftikhar, S.A. Khan, M.J. Jaska- ni, Samiullah and R.M.S. Tariq. 2015. Quick indexing of Huanglongbing on the basis of symptomology and iodo-starch test in relation to environmental factors. Pak. J. Agric. Sci., 52(4):1005-1009.

Salisbury, F.B. and C.W. Ross. 1992. Plant Physiology, Hormones and Plant Regulators: Auxins and Gibberellins. $4^{\text {th }}$ Edition, Wadsworth Publishing, Belmont, 357-381.

Shafiee, M., T.S. Taghavi and M. Babalar. 2010. Addition of salicylic acid to nutrient solution combined with post-harvest treatments (hot water, salicylic acid, and calcium dipping) I improved postharvest fruit quality of strawberry. Sci. Hortic., 12(4): 40-50. https://doi. org/10.1016/j.scienta.2009.12.004

Shokrollah, H., T.L. Abdullah, K. Sijam and S.N.A. Abdullah. 2011. Potential use of selected citrus rootstocks and inter stocks against HLB disease in Malaysia. Crop Prot., 30(5): 521-525. https://doi.org/10.1016/j.cropro.2010.09.005

Shukla, S., E. Kavak, M. Gregory, M. Imashimizu, B. Shutinoski, M. Kashlev and S. Oberdoerffer. 2011. CTCF-promoted RNA polymerase II pausing links DNA methylation to splicing. Nature, 479(7371): 74. https://doi. org/10.1038/nature10442

Srivastava, P.C. and U.C. Gupta. 1996. Trace elements in crop production. Science Publishers, Lebanon, 356.

Stelinski, L.L. 2019. Ecological aspects of the vector-borne bacterial disease, citrus greening (Huanglongbing): dispersal and host use by Asian citrus psyllid, Diaphorina citri Kuwayama. Insects., 10(7): 208. https://doi.org/10.3390/ insects 10070208

Suresh, V., M. Ammaan and R.P. Jagadeeshkanth. 2018. An over view of micronutrients on growth, yield and quality of citrus. Int. J. Horti., 8(14):163-170. https://doi.org/10.5376/ ijh.2018.08.0014

Swietlik, D., 2002. Zinc nutrition of fruit trees by foliar sprays. Acta Horticulturae., 93: 123129. https://doi.org/10.17660/ActaHortic.2002.594.11

Tariq M., M. Sharif, Z. Shah and R. Khan. 2007. Effect of Foliar Application of Micronutrients on the Yield and Quality of Sweet Orange (Citrus sinensis L.). Pak. J. Biol. Sci., 10:1823-1828. https://doi.org/10.3923/pjbs.2007.1823.1828

Thomas, C.C. and C. Lovatt. 2004. Application 
of plant growth regulators and/or fertilizers to increase fruit set fruit size and yield of clementine mandarin. Citrus research board. Botany and plant sciences, UC/Riverside, USA.

Tipu, M.M.H., M.M. Rahman, M.M. Islam, F.E. Elahi, R. Jahan and M.R. Islam. 2020. Citrus greening disease (HLB) on Citrus reticulata (Mandarin) caused by Candidatus Liberibacter asiaticus in Bangladesh. Physiol. Mol. Plant Pathol., 112: 101558.https://doi.org/10.1016/j. pmpp.2020.101558

Tran, T.T., K. Clark, W. Ma and A. Mulchandani. 2020. Detection of a secreted protein biomarker for citrus Huanglongbing using a single-walled carbon nanotubes-based chemo receptive biosensor. Biosens. Bioelectron., 147: 111766. https://doi.org/10.1016/j.bios.2019.111766

Wang, N.2019. The citrus Huanglongbing crisis and potential solutions. Mol. Plant.,12(5): 607-609. https://doi.org/10.1016/j.molp.2019.03.008

Zhang, X.H., N. Pizzo, M. Abutineh, X.L. Jin, S. Naylon, T.L. Meredith, J.M. Harlin. 2020. Molecular and cellular analysis of orange plants infected with Huanglongbing (citrus greening disease). Plant Growth Regul., 92(2): 333-343. https://doi.org/10.1007/s10725-020-00642-z 